\title{
Rebellion of Caius Iulius Vindex against Emperor Nero
}

\author{
K. Królczyk
}

For citation: Królczyk K. Rebellion of Caius Iulius Vindex Against Emperor Nero. Vestnik of Saint Petersburg University. History, 2018, vol.63, issue 3, pp.858-871. https://doi.org/10.21638/11701/ spbu02.2018.312

The article discusses the rebellion led by Caius Iulius Vindex (the governor of the Roman province of Gaul) against emperor Nero. Vindex, who was disheartened with the policy of the princeps, wanted Nero's place on the Roman throne to be taken by a person worthy of being a proper successor to Caesar and Augustus. This was the main reason for his revolt, which began in the middle of March 68 AD. Vindex's insurgence was largely supported by the Gauls and the governor of the province of Hispania Tarraconensis, i.e. Servius Sulpicius Galba. However, his troops were crushed by the joint contingent from Upper and Lower Germany under the command of L. Verginius Rufus in the battle of Vesontio, which took place between the end of April and the middle of May $68 \mathrm{AD}$ (the exact date cannot be established). As a result, C. Iulius Vindex committed suicide. Nevertheless, the anti-emperor movement started by Vindex grew stronger, and eventually Nero, abandoned by everyone, took his own life on June 9, and Vindex's former ally, Galba, became the new emperor. The principal goal of the rebellion, i.e. replacing Nero with a new ruler of a better character was ultimately achieved, albeit after Vindex's tragic death. These events were also a prelude to "the long year" (annus longus) or the so called "the year of the four emperors". After his death, the leader of the anti-Nero revolt was honored by the new emperor Galba with a public funeral. Until the times of the late antiquity, the person of Caius Iulius Vindex had embodied in Roman collective memory an indomitable freedom defender (adsertor libertatis), who desired the good of the Roman Empire and the entire gens humana.

Keywords: Vindex, Nero, Roman Empire, rebellion, revolt, 68 AD.

\section{Восстание Гая Юлия Виндекса против императора Нерона}

\section{К. Крульчык}

Для цитирования: Królczyk K. Rebellion of Caius Iulius Vindex Against Emperor Nero // Вестник Санкт-Петербургского университета. История. 2018. Т. 63. Вып. 3. С. 858-871. https://doi. org/10.21638/11701/spbu02.2018.312

Krzysztof Królczyk - PhD, Professor, Institute of History, Adam Mickiewicz University in Poznań, 89d, Umultowska str., Poznań, 61-614, Poland; krolczyk@amu.edu.pl

Кшиштоф Крульчык - PhD, профессор, Институт истории, Университет им. Адама Мицкевича в Познани, Польша, 61-614, Познань, ул. Умультовска, 89d; krolczyk@amu.edu.pl

A preliminary version of this text was prepared in Polish within the scholar grant "The Transformation of the Roman Empire under the Flavian Dynasty" funded by Department of Scientific Research of the Polish Ministry of Science and Higher Education (Nr. 108 058335).

Предварительная версия статьи была подготовлена на польском языке в рамках научного гранта департамента научных исследований польского министерства науки и высшего образования «Трансформация Римской империи при династии Флавиев» (№ 108 058335).

(c) Санкт-Петербургский государственный университет, 2018 
В настоящей статье обсуждается восстание, вспыхнувшее в Римской империи против римского императора Нерона. Его лидером был Гай Юлий Виндекс, одно время губернатор Римской провинции Галлии. Виндекс, разочарованный политикой принцепса, хотел, чтобы место Нерона на римском троне занял более достойный человек, надлежащий преемник Гая Юлия Цезаря и императора Августа. Это было основной причиной восстания, которое началось в середине марта 68 г. н. э. Восстание Гая Юлия Виндекса было в значительной степени поддержано губернатором провинции Hispania Tarraconensis, т.е. Сервием Сульпицием Гальбой, и, кроме того, галлами. Однако войска Виндекса были раздавлены в битве при Vesontio совместным военным контингентом из Верхней и Нижней Германии под командованием Л. Вергинюса Руфуса в конце апреля - середине мая 68 г. н.э. В результате Гай Юлий Виндекс покончил жизнь самоубийством. После его смерти антиимператорское движение, им начатое, усилилось, и в конце концов Нерон, оставленный всеми, 9 июня покончил с собой, а бывший союзник Виндекса С. Сульпиций Гальба стал новым римским императором. Основная цель восстания - замена Нерона новым, лучшим правителем, была в конечном счете достигнута, хотя и после трагической смерти Виндекса. Эти события послужили также прелюдией к «длинному году» (annus longus), или так называемому «году четырех императоров». Глава восстания после своей смерти был удостоен новым императором публичными похоронами. Кроме того, в римской коллективной памяти, по крайней мере до времен поздней античности, Гай Юлий Виндекс оставался символом неукротимого защитника свободы (adsertor libertatis), который желал блага Римской империи и всему человечеству (gens humana).

Ключевые слова: Виндекс, Нерон, Римская империя, восстание, восстание 68 г. н.э.

The last years of the reign of Emperor Nero $^{1}$ were fraught with political conflicts. In $65 \mathrm{AD}, \mathrm{C}$. Calpurnius Piso authored an unsuccessful plot whose main purpose was to take the life of the princeps ${ }^{2}$. Although this assassination attempt was promptly thwarted, it resulted in various forms of repression that amplified an already growing negative attitude towards the emperor. There was political unrest in the provinces. In $66 \mathrm{AD}$, a military uprising against the Roman rule was organized by the Jews ${ }^{3}$. The social unrest caused by, among other things, excessive taxation was also felt in the Western part of the Empire, namely Britain and Gaul (Cass. Dio 63.22.1a; Zon. 11.13.B). In the last case, the unrest evolved into a military revolt against the reign of Nero led by Caius Iulius Vindex (Гáıoৎ

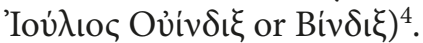

Vindex's rebellion merits an in-depth analysis as it resulted in the fall and death of the last representative of the Julio-Claudian dynasty on the Roman throne, giving rise

${ }^{1}$ Prosopographia Imperii Romani saec. I, II, III, editio altera (further - PIR ${ }^{2}$ ), D, n ${ }^{\circ}$ 129; Hohl E. Domitius (Nr. 29) // Realencyclopädie der classischen Altertumswissenschaft (further - RE), Supplement band III. 1918. S. 349-394; see also: Grant M. Neron. Warszawa, 1980. P. 179; Griffin M. T. Nero. The End of a Dynasty. $3^{\text {rd }}$ ed. London, 2000. S. 164-188; Waldherr G. H. Nero. Eine Biographie. Regensburg, 2005. S. 246-262.

2 The Piso's conspiracy and its end: Tacitus, Annales (further - Tac., Ann.)15.48-74; see also: Rogers R.S. Heirs and Rivals to Nero // Transactions and Proceedings of the American Philological Association. 1955. Vol. 86. P. 190-212, especially p. 207.

3 For more on this subject, see among others: Smallwood E.M. The Jews under Roman Rule. From Pompey to Diocletian. Leiden, 1976. P. 293-330; Bloom J. J. The Jewish Revolt against Rome, A. D. 66-135. A Military Analysis. Jefferson; London, 2010. P. 16-176.

4 Plutarch (Galba 4.2) gives an incorrect version of the leader's name: Iunius Vindex (Iov́vıoc Ov̉iv $\delta ı \xi)$ ). More on Caius Iulius Vindex see: PIR ${ }^{2}$ I, n ${ }^{0}$ 628; Fluss M. Iulius (Nr. 534) // RE X / Hrsg. von W. Kroll. Stuttgart, 1918. S. 879-881. 
to a period of civil wars in the Roman Empire, also known in the literature as "the year

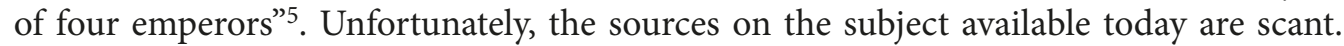
P.Cornelius Tacitus, the greatest Roman historian in his Historiae, an invaluable work describing the difficult period of 69-70 AD, starts his narration on 1 January $69 \mathrm{AD}$ (Tac., Hist. 1.1.1: "Initium mihi operis Servius Galba iterum Titus Vinius consules erunt") ${ }^{6}$, which means that Vindex's rebellion was completely omitted by him, and there are only sporadic passing references to it, when he describes other events (for example, Tac., Ann. 15.74.2; see also: Tac., Hist. $1.6 .2 ; 8.1 ; 51.1 ; 53.3 ; 65.2 ; 70.1 ; 89.1 ; 4.57 .2)$. In such a case, in order to reconstruct the events we need to use the works by Suetonius (the lives of Nero, Galba, and Othon) as well as Plutarch (the lives of Galba and Othon), "Roman history" by Cassius Dio from the third century, preserved until today partially not in its original form, but in a medieval copy made by a Byzantine monk Xyphilinos ${ }^{7}$. The scarcity of sources makes it difficult to analyze the events and reconstruct their detailed chronology.

G. Iulius Vindex was a representative of the Gaul (more adequately: Aquitan) tribal

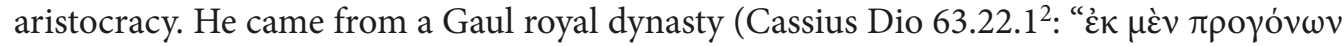

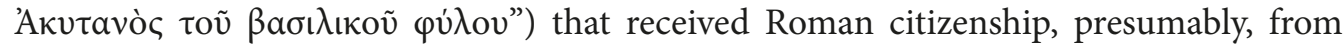
Julius Caesar. Vindex was also a son of a Roman senator ${ }^{8}$. His exact date of birth is, unfortunately, unknown. According to M. Fluss it could have taken place in ca. $25 \mathrm{AD}^{9}$, which seems quite likely. In the decisive for the later events period, Vindex held the office of legatus Augusti pro praetor, i.e. he was the Roman governor of one the Gallic provinces. Most scholars agree that the province in question was presumably Gallia Lugdunensis ${ }^{10}$,

5 The expression "year of four emperors" is a contemporary invention. Tacitus in his "Dialogue on Orators" (17.3) names it a "one and long year of Galba, Othon and Vitelius" ("Galbae et Othonis et Vitellii longus et unus annus"). For more information on the events in 68-69 A. D. see: Henderson B. W. Civil War and Rebellion in the Roman Empire A.D. 69-70. A Companion to the 'Histories' of Tacitus. London, 1908; Greenhalgh P. A. L. The Year of Four Emperors. London, 1975; Wellesley K. The Year of the Four Emperors. $3^{\text {rd }}$ ed. London; New York, 2000; Morgan G. 69 A.D. The Year of Four Emperors. Oxford, 2006; see also: Wiedemann T.E.J. From Nero to Vespasian // The Cambridge Ancient History. Second ed. Vol. 10. The Augustan Empire, 43 B.C. - A.D. 69. $5^{\text {th }}$ ed. / eds A.K. Bowman, E. Champlin, A.Lintott. Cambridge, 2009. P. 256-282; Pfeiffer S. Die Zeit der Flavier. Vespasian - Titus - Domitian. Darmstadt, 2009. S.3-13; Kozłowski J., Królczyk K. Aspekty polityczne i militarne "roku czerech cesarzy" (68-69 r. po Chr.), part 1. Do śmierci Galby // Studia Europaea Gnesnensia. 2015. T.11. S.29-54; Kozłowski J., Królczyk K. Aspekty polityczne i militarne "roku czerech cesarzy" (68-69 r. po Chr.), part 2. Od śmierci Galby do zwycięstwa Wespazjana // Studia Europaea Gnesnensia. 2015. T. 12. S. 33-60; Byra M. Wojna o tron cezarów (68-69 r. n.e.). Oświęcim, 2014.

${ }^{6}$ More on possible motivations of Tacitus' choice, see: Hainsworth J. B. The Starting-Point of Tacitus' Historiae: Fear or Favour by Omission? // Greece \& Rome. Second Series. 1964. Vol. 11. P. 128-136.

7 For more on the matter, see: Murison C.L. Rebellion and Reconstruction: Galba to Domitian. An Historical Commentary on Cassius Dio's Roman History, Books 64-67 (A.D. 68-96). Atlanta (Georgia), 1999. P. 1; see also: Millar F. A Study of Cassius Dio. Oxford, 1964. More on Xyphilinos: Ziegler K. Xyphilinos // RE IX A / Hrsg. von K. Ziegler, W. John. Stuttgart, 1967. S. 2132-2134.

8 On the question of giving Roman citizenship to Vindex's family by Caesar: PIR ${ }^{2}$ I, n ${ }^{\circ}$ 628, 294; Fluss M. Iulius (Nr. 534)... S. 879; Domaszewski A.von. Geschichte der römischen Kaiser. Bd. 2. 3 Aufl. Leipzig, 1921. S.74.

9 Fluss M. Iulius (Nr. 534).... S. 879.

10 Suetonius (Nero 40) merely mentions that Vindex was a governor of Gaul without giving the actual name of the province. It is, however, known that the governor of Aquitania was against Vindex's actions, so he (i.e. Vindex) could not have governed Gallia Aquitania. Most scholars agree that Vindex was the governor of Gallia Lugdunensis (e.g. Shotter D. C. A. A Time-Table for the 'Bellum Neronis' // Historia. Vol.24. 1975. P. 61. According to Murison Ch. L. Galba, Otho and Vitellius: Careers and Controversies. Hildesheim; Zürich; New York, 1993. P. 10, fn. 31. Gallia Belgica and Gallia Narbonensis also seem likely to have been governed 
although such a conclusion is not based on the sources. For Suetonius, Vindex was the "head of that province", i.e. Gaul (Suet., Nero 40.1: "qui tum eam provinciam pro praetore optinebat"), a similar sentiment was expressed by Plutarch (Plut., Galba 4.2: "Гa $\lambda \alpha \tau i a c$

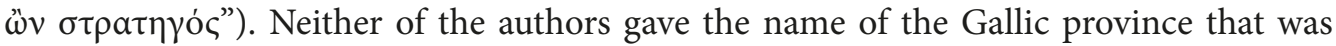
governed by Vindex. For Cassius Dio, on the other hand, he was the leader of Gauls (Cass.

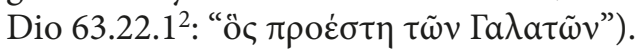

The details of G. Iulius Vindex's governorship in Gaul are not known today; we do not even know when he was appointed to the office. Dietmar Kienast is of the opinion that he was probably given the position as late as $67 \mathrm{AD}^{11}$. It is, however, certain that Vindex was dissatisfied with Nero's reign. This is known thanks to Cassius Dio's account. The historian from Bithynia, in a fictional speech delivered by the governor, points to the taxes levied on the province of Gaul, which must have resulted in an understandable level of frustration among its inhabitants (Cass. Dio 63.22.1a and 22.2). Nevertheless, this is not the only reason why Vindex resented the emperor. To Vindex, Nero was not fit to hold the highest office in the country. His reign resulted in "a diminished role of all

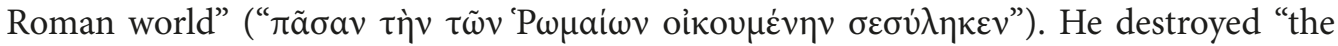

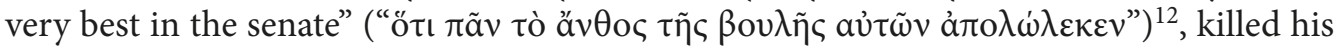
own mother and, to cap it all, he also played parts in theatre plays and sang. Judging by the

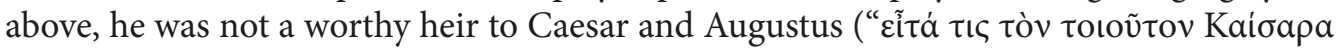

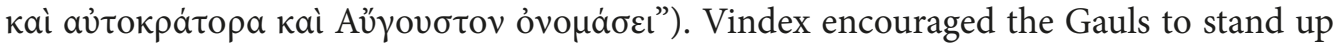

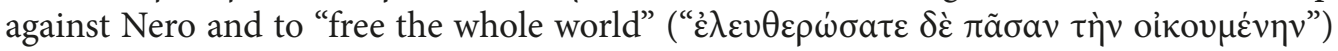
(all these statements come from Cass. Dio 63.22.3-6) ${ }^{13}$. Similar arguments against Nero were given in the account by Flavius Philostratus in his Vita Apollonii from Tyana (Filostr., Vit. Apoll. 5.10). According to Philostratus, the governor believed that the emperor was a terrible musician, although in the eyes of Vindex it still would have been better for Nero to play the cithara than to govern the Roman Empire. G. Iulius Vindex believed that Nero possessed such negative virtues as: insanity ( $\mu \alpha v i \alpha)$; greed for money ( $\varphi$ i $\left.{ }_{0} \chi \rho \eta \mu \alpha \tau i \alpha\right)$,

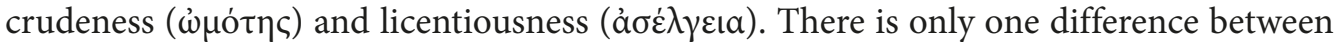
the account of Cassius Dio and that of Filostratos: the author of Vita Apollonii is convinced that Vindex did not accuse the emperor of matricide despite the fact that, in his opinion, it was his most abhorrent deed. This accusation is mentioned in Dio's text. Juvenalis, on the other hand, in his eighth "Satire", expresses the view that Nero's ferocity was the reason for Vindex's revolt (Iuv. 8.222).

In the old literature it was assumed that Vindex, often seen as the "national" leader of Gauls, and compared to Sacrovir and Civilis, intended to overthrow Nero's regime and to free all the whole Gaul from the Roman rule ${ }^{14}$. Such an understanding of Vindex's

by Vindex; Levick B. L. Verginius Rufus and the Four Emperors // Rheinisches Museum für Philologie. 1985. Bd. 128. S.318. - Levick thinks that it was possible that he was the governor of Gallia Belgica. On the other hand, Brunt is convinced that Vindex can't have been the governor of Belgic Gaul: Brunt P. A. The Revolt of Vindex and the Fall of Nero // Latomus. 1959. Vol. 18. P. 532. Fn. 2.

11 Kienast D., Eck W., Heil M. Römische Kaisertabelle. Grundzüge einer römischen Kaiserchronologie. 6. bearb.. Aufl. Darmstadt, 2017. S. 92.

${ }^{12}$ Here Vindex alludes to the persecution and death sentences issued after uncovering of the conspiracy of Piso.

13 For a critical account of Vindex's speech, see: Brunt P. A. The Revolt... P. 533-534.

14 This was the opinion of, for instance: Henderson W. Life and Principate of the Emperor Nero. London, 1903. P. 399; his views was still shared by: Syme R. Tacitus. $2^{\text {nd }}$ ed. Oxford, 1997. Vol. 1. P. 462 ("However it be, the protest against the tyranny of Nero at once and inevitably took the form of a native insurrection 
revolt today is seen as anachronistic ${ }^{15}$. Old historiographers went as far as to wrongly, from our perspective, believe that Vindex desired to overthrow monarchy and restore republic in Rome, a hypothesis supported by Theodor Mommsen ${ }^{16}$, among others. It is difficult to assume that the governor of Gaul wanted to resurrect the republican rule since his ancestors did not have Roman citizenship in that period of time ${ }^{17}$, which means that Vindex could only have a faint idea of what Res Publica Romana was and how it functioned. It seems clear that all his actions and propagandist coin legends (discussed below) were oriented towards the ultimate goal of improving the political situation in the country. To Vindex, this could be achieved only by removing a bad emperor and instituting a better heir to the throne, worthy of continuing the traditions of Augustus' principate. It should be noted that Vindex did not desire the title of the emperor for himself (Cass. Dio 63.23) ${ }^{18}$.

At the beginning of winter $67 / 68 \mathrm{AD}$, Vindex appealed in writing to other province governors to denounce Nero and overthrow him (Plut., Galba 4.2). One of those letters was addressed to Servius Sulpicius Galba, a senator of over seventy years of age at the time, who had been the governor of Hispania Tarraconensis for the last eight years (Suet., Galba 9.1; Plut., Galba 4.2 ${ }^{19}$. Cassius Dio, as well as Zonaras, recount that to Vindex Galba was the future princeps, the successor of Nero (Cass. Dio 63.23; Zon. 11.13). It is quite interesting that almost at the same time, Galba received an urgent formal request from the governor of Aquitania to suppress rioting in Gaul (Suet., Galba 9.2). According to Plutarch, Galba initially did not want to react at all: he neither wanted to respond to Vindex's letter, nor informed the emperor about it, calmly awaiting further developments. Galba's attitude was an exception to that of other governors, as all other officials contacted by Vindex informed the Caesar about the correspondence (Plut., Galba 4.2). Their actions were probably motivated by a widespread fear of Nero among Roman nobility resulting from repressions following the Piso's plot.

Although no positive answers were received from other governors, Vindex decided not to wait any longer, and in the middle of March $68 \mathrm{AD}^{20}$ he started a military uprising that Tacitus briefly referred to as bellum Neronis (Tac., Hist. 2.27.2), bellum Vindicis (Tac., Hist. 1.70.1), bellum adversus Vindicem (Tac., Hist. 1.53.2), conatus Vindicis (Tac., Hist. 1.65.2) and motus Vindicis (Tac., Hist. 1.89.1). The leader of the uprising had the backing of the Gaul tribes from Aquitania (the Arveni: Tac., Hist. 4.17.3), Belgian Gaul (the Sequani: Tac., Hist. 1.51.4) and Galia Lugdunensis (the Aedui: Tac., Hist. 1.51.4 and 4.17.3). Josephus in a more general manner notes that the leaders of Gaul tribes supported Vindex

against the Roman power, recalling Julius Florus and Julius Sacrovir, chieftains of the Treverians and Aedui, who raised war in Gaul in the days of Tiberius Caesar").

${ }^{15}$ See, for example: Wiedemann T.E. J. From Nero... P. 258. - Brunt convincingly argues against the idea that Vindex rebelled to free Gaul and Gauls from the Roman rule: Brunt P. A. The Revolt... P. 543-559.

${ }_{16}$ Mommsen T. Der letzte Kampf der römischen Republik // Mommsen T. Historische Schriften.

Bd. 1. Berlin, 1906. S.333-352.

17 This is pointed out by: Wiedemann T.E. J. From Nero... P. 257.

${ }_{18}$ For more on the subject of Vindex's propaganda efforts, see: Brunt P. A. The Revolt... P. 533-534.

19 On Galba see, for example, in: PIR ${ }^{2}$ S, n ${ }^{\circ}$ 1003; Fluss M. Sulpicius (Nr. 63) // RE IV A / Hrsg. von W. Kroll, K. Mittelhaus. Stuttgart, 1931. S.772-801.

20 There is a hypothesis that the rebellion started on the day of Idus Martiae, so on $15 \mathrm{March}$, the anniversary of Julius Caesar assassination; see Hainsworth J. B. Verginius and Vindex // Historia. Vol.11. 1962. P. 87; this assumption is not dismissed by: Murison Ch.L. Galba, Otho and Vitellius... P.5. On the other hand, Shotter believes that it happened around $11^{\text {th }}$ of March (Shotter D. C. A. A Time-Table... P. 64). 


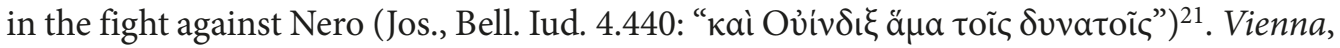
a colony in Gallia Narbonensis, also supported Vindex (Tac., Hist. 1.65.2). It appears that the rebellion was also backed by the tribe of Batavi. Tacitus noted that Fonteius Capito, an army general in the lower Germania, ordered the murder of Claudius Paulus, one of the Batavi leaders, while the other one, i.e. Iulius Civilis, who later became the leader of the Batavi uprising, chained, was sent to the emperor. Capito took such steps as both Batavian leaders were accused of taking part in the rebellion ${ }^{22}$. According to Plutarch, Vindex could call up an army of 100.000 supporters, which seems to be an overstated estimate (Plut., Galba 4.3 $)^{23}$. The otherwise unknown tribe leaders loyal to Vindex were Asiaticus, Flavus and Rufinus, who were later executed by Vitelius (Tac., Hist. 2.94.2). It should also be noted that Vindex had no legion at his disposal in his province, so Tacitus goes as far as to call his province "defenseless" (cum inermi provincia). Thus, it comes as no surprise that he was looking for supporters in the provinces where Roman legions were stationed.

At the same time, the capital of Galia Lugdunensis, the city of Lugdunum, founded by Romans, remained faithful to the emperor. The city received a generous donation of four million sestertii after a recent fire, and there was an ongoing conflict between Lugdunum and Vienna loyal to Vindex ${ }^{24}$. In addition, the part of Gaul located on the banks of the Rhine (Tac., Hist. 1.16.1: pars Galliarum quae Rhenum accolit) was against Vindex's revolt, as were the tribes of Treveri and Lingones (Tac., Hist. 4.69.2).

Vindex's presumably first step was to lay siege to Lugdunum, a city that opposed the rebellion ${ }^{25}$. Vindex also launched a wide-ranging propaganda that portrayed him as the savior of the Roman world. As part of those efforts coins were struck by the initiative of the governor of Gaul in a provincial mint that was supposedly based in Vienna ${ }^{26}$. There are at least a dozen known monetary types. One of the most common monetary type depicts Victoria, i.e. the goddess of victory, standing on a globe with a laurel wreath and a palm branch in her hands. The legend reads GENERIS HVMANIS. On the reverse, there is a wreath made of oak leaves encircling the letters SPQR (RIC I, The Civil Wars, $\left.\mathrm{n}^{0} 68-69,71-73,77\right)^{27}$. Other issues depict Victoria writing the letter $\mathrm{V}$ on her shield (with the same legend and reverse as in the example discussed above - RIC I, The Civil Wars, $\mathrm{n}^{0} 75$ and 76$)^{28}$. Sometimes the goddess of victory was accompanied by Mars the

${ }^{21}$ Cf. Shotter D. C. A. A Time-Table ... P. 61.

${ }^{22}$ For Tacitus (Hist. 4.13.1), those accusations were false; however, as it was proved by: Shotter D. C. A. A Time-Table... P.62, the harsh treatment of Gaius Fonteius Capito by Galba, was reminiscent of his treatment of Vindex's supporters in the region of Lower Rhine. On the other hand, L. Bessone (Bessone L. Le vicissitudini di Gulio Civile e la datazione delle battaglia di Vesontio // Latomus. 1978. Vol. 37. Fasc. 3. P.710-713) makes a connection between the assassination of Paulus and Civilis's departure for Rome and the events after the battle of Vesontio, when the Batavi showed great support for Verginius Rufus, in this way antagonizing Fonteius Capito, who was loyal to Nero.

${ }^{23}$ See: Brunt P. A. The Revolt... P. 532.

${ }^{24}$ On Vienna standing up against Vindex's revolt, see: Tac., Hist. 1.51.5; on the financial support for Lugdunum: Tac., Ann. 16.13; on the rivalry between Vienna and Lugdunum: Tac., Hist. 1.65; on the fire in Lugdunum mentioned by Seneca: Epistulae Morales 91.14.

25 Shotter D. C. A. A Time-Table... P. 66. On the reasons behind the siege of Lugdunum by Vindex, see also: Morgan G. 69 A. D. The Year... P. 22.

26 Roman Imperial Coinage I, The Civil Wars. P. 198.

27 RIC I, The Civil Wars, $n^{\circ} 68,73$ : "Victoria turned to the right"; $n^{\circ} 69,71-72$ : "Victoria turned to the left"; $n^{\circ} 77$ : "Victoria turned to the left"; the reverse read SPQR OB C(ives) S(ervatos).

${ }^{28}$ On the reverse of the last coin, apart from the letters SPQR, the writing OB C(ives) S(ervatos) was also included. 
Avenger (Ultor) on the reverse (RIC I, The Civil Wars, $\mathrm{n}^{\circ}$ 67). Other common legends on Vindex's coins were: ROMA RESTITVTA (RIC I, The Civil Wars, $\mathrm{n}^{\circ}$ 60-63) (or just ROMA: RIC I, The Civil Wars, ${ }^{\circ}$ 59), SECVRITAS (RIC I, The Civil Wars, ${ }^{\circ} 37-38$ ), PACI AVGVSTAE (RIC I, The Civil Wars, ${ }^{\circ} 56$ ), PAX ET LIBERTAS (RIC I, The Civil Wars, ${ }^{\circ}$ 57-58), SALVS ET LIBERTAS (RIC I, The Civil Wars, no. 64-66), CONCORDIA ORB(is) TER(rarum) (RIC I, The Civil Wars, ${ }^{\circ} 41$ ), GENIVS P(opuli) R(omani) (RIC I, The Civil Wars, $\mathrm{n}^{\circ} 42-46$ ) and VIRTVS (RIC I, The Civil Wars, $\mathrm{n}^{\circ}$ 78-78A). Among the gods visible on Vindex's coins, apart from Victoria, there were: IVPPITER OPTIMVS CAPITOLINVS (RIC I, The Civil Wars, $\mathrm{n}^{\circ} 42$ ), IVPPITER CONSERVATOR (RIC I, The Civil Wars, $\mathrm{n}^{\circ} 40$ and 60), IVPPITER CVSTOS (RIC I, The Civil Wars, $\mathrm{n}^{\circ} 59$ and 78), IVPPITER LIBERATOR (RIC I, The Civil Wars, $\mathrm{n}^{\circ} 62$ ), MARS VLTOR (RIC I, The Civil Wars, $\mathrm{n}^{\circ} 43,47-48,50-55$ and 67), VOLCANVS VLTOR (RIC I, The Civil Wars, $\mathrm{n}^{\circ} 79$ 80), HERCVLES ADSERTOR (RIC I, The Civil Wars, $\mathrm{n}^{\circ} 49$ ), PIA FELICITAS (RIC I, The Civil Wars, $n^{\circ} 41$ ), FLORENS FORTVNA (RIC I, The Civil Wars, ${ }^{\circ} 49$ ), PAX (RIC I, The Civil Wars, $\mathrm{n}^{\circ} 56$ and 74), ROMA (RIC I, The Civil Wars, $\mathrm{n}^{\circ}$ 59-63). Other variations of the reverse, besides SPQR surrounded by a wreath of oak leaves, included coins with the letters SIGNA P(opuli) R(omani) (RIC I, The Civil Wars, $\mathrm{n}^{0} 39,45,50-51,57,63$, $70,80)$. The choice of monetary motifs, the characteristic gods with certain cult epithets and the words used for the legends (in particular, the epithet adsertor, may seem similar to vindex, the cognomen of the revolt's leader) clearly illustrate Vindex's objectives: a restoration of Imperium Romanum (also in the moral sense) that would be possible after overthrowing the tyrant ${ }^{29}$. Furthermore, this statement can be eventually strengthened by other Vindex's coins showing the head of Augustus on the obverse with the legend AVGVSTVS DIVI F(ilius) and the inscription OB CIVES SERVAT(os) within oak-wreath on the reverse (RIC I, The Civil Wars, $\mathrm{n}^{\circ} 102$ ) - in this case, C. Iulius Vindex was to be seen as a real follower of the policy of Augustus, as a person who carries out the whole process of restoration of Imperium Romanum and who saves the Roman citizens as the first emperor of Rome did.

Nero learnt about the rebellion in Gaul during his stay in Naples. Suetonius states that the emperor first heard about the events on 24 March, the anniversary of Agrippina's death (Suet., Nero 40.4) ${ }^{30}$. In the beginning, Nero is said to have remained calm. Instead of reacting nervously, the emperor was looking at wrestlers fighting. For eight days, he had not made any decisions, which led some to suspect that he was secretly glad that he was going to be able to loot such a rich province, according to the law of war (Suet., Nero $40.4)^{31}$. With time, however, the princeps became more agitated. It was not because he felt threatened by Vindex, but because he (i.e. Vindex) had the temerity to criticize the emperor's stage performance, described him as "bad citharist" (malus citharoedus) while using the family surname of Ahenobarbus instead of the one assumed at the moment of taking over the power, thus refusing the emperor the right to be a heir of Augustus. Consequently, Nero called the senate to avenge the insults to his person (Suet., Nero 41.1).

${ }^{29}$ For more information on the subject of Vindex's coins, see: Kraay C. M. The Coinage of Vindex and Galba, AD 68, and the Continuity of the Augustan Principate // Numismatic Chronicle. 1949. Vol.9. P. 129-149; RIC I, The Civil Wars. P. 198-199.

${ }_{30}$ More general information on the date of Nero's mother death: Murison Ch.L. Galba, Otho... P. 4-5; see also: Kienast D., Eck W., Heil M. Römische Kaisertabelle... S. 87.

31 See also: Brunt P. A. The Revolt... P. 540. 
Finally, the princeps decided to go back to Rome. His state of mind much improved when on the way to the capital he saw a monument representing a Roman soldier prevailing over a Gallic warrior. In view of the above, Nero decided not to call an extraordinary senate meeting, but to hold a counsel with a small group of distinguished Romans (primori viri) (Suet., Nero 41.2).

The situation changed completely at the beginning of April $68 \mathrm{AD}$ when, after a short period of waiting, Galba finally reacted to the events. According to Plutarch's account, Vindex, having openly disobeyed Nero, wrote to Galba once again, asking him to join the rebellion and offering him the leadership over the campaign (Plut., Galba 4.3-4). In the words of Suetonius, Vindex wanted Galba to be "the savior of Humankind and leader" (Suet., Galba 9.2: "ut humano generi assertorem ducemque se accommodaret"). The governor of Spain was hesitant and asked his friends for advice first. He was finally convinced by Titus Vinius, a legate of the Spanish IV legion ${ }^{32}$. It is possible that other factors were also taken into account: apparently, a letter from Nero ordering the assassination of Galba was intercepted (Suet., Galba 9.2). This could have been an argument against obeying the emperor. Officially, Galba joined the anti-emperor league in Cartagena (Carthago Nova), and his soldiers gathered there immediately hailed him as the emperor (Suet., Galba 10.1; Plut., Galba 5.2). The governor of Spain rejected the title of Caesar, but accepted the title of the legate of the Senate and Rome (Suet., Galba 10.1: "legatus senatus ac populi Romani";

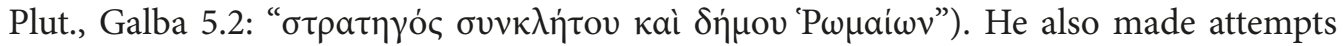
to find new supporters for the cause. He managed to win over M. Salvius Otho, at the time the governor of the neighboring province of Lusitania, who, according to Suetonius, was "the first to join the attempts of Galba" (Suet., Otho 4.1: "conatibus Galbae primus accessit") ${ }^{33}$. Among his other followers were Aulus Caecina, the quaestor of Baetica (Tac, Hist. $1.53,1)^{34}$, then Q. Pomponius Rufus, who held the office of praefectus orae maritimae Hispaniae Citerioris Galliae Narbonensis ${ }^{35}$, and also, possibly, the prefect of Egypt Tib. Iulius Alexander ${ }^{36}$. Moreover, Galba did not neglect the preparations for the military campaign; he made efforts to collect financial resources and to form new military entities, including one legion unofficially known as Galbiana ${ }^{37}$. The new regiment was ready to go to war before 10 June $68 \mathrm{AD}$ that was later celebrated as the festive day of this legion each year ("dies natalis aquilae") 38 .

The alliance between Vindex and Galba is confirmed on the coins issued on behalf of the governor of Spain. The motifs used in Galba's minting practice allude to those visible on Vindex's issues described above ${ }^{39}$. There are, however, some new elements. We have coins that represent Galba's head and the legend GALBA IMP(erator) with the personifications of Spain and Gaul shaking their right hands on the reverse of the coin (legend GALLIA

32 On the date Galba joined Vindex, see: Murison Ch.L. Galba, Otho... P. 30 ("about 3 April 68"); Brunt P.A. The Revolt... P.535 ("on 6 April"); Kienast D., Eck W., Heil M. Römische Kaisertabelle... S. 102 (“Anf. April 68”).

${ }^{33}$ For more information on Othon, see $\mathrm{PIR}^{2} \mathrm{~S}, \mathrm{n}^{\circ}$ 143; Nagl A. Salvius ( $\left.\mathrm{n}^{\circ} 21\right) / / \mathrm{RE}$ I A / Hrsg von W. Kroll, K. Witte. Stuttgart, 1920. S. 2035-2055.

34 See also: Shotter D. C. A. A Time-Table... P. 63.

35 Inscriptions of Roman Tripolitania 537; Shotter D. C. A. A Time-Table... P. 63.

${ }^{36}$ Brunt P. A. The Revolt... P. 536; Shotter D. C. A. A Time-Table... P. 63; see also: Turner E. G. Tiberius Iulius Alexander // Journal of Roman Studies. 1954. Vol. 44. P. 60.

37 For additional source information on the forming of the legion, see: Tac., Hist. 2.11.1; 3.22.4; 3.25.2.

38 Ritterling E. Legio // RE XII / Hrsg. von W. Kroll. 1924-1925. S. 1629.

39 Wiedemann T.E.J. From Nero... P. 256-257. 
HISPANIA (RIC 1, Galba, $\mathrm{n}^{\circ} 15-18$ ). Another monetary type depicts Galba riding a horse with a spear in his hand and, on the reverse - three female busts symbolizing the three provinces of Gaul. The legend reads TRES GALLIA[E] (RIC 1, Galba, $n^{\circ}$ 89-92). One of the most prominent symbols of the period is a dinar coin with the personifications of Spain and Gaul with the goddess of victory standing between them on the globe holding a wreath of laurel leaves in her hand. The legend of this coin is also interesting, as it lauds the agreement between the Gallic and Spanish provinces: CONC[ORDIA HI]SPANIARVM ET GALLIARVM. The reverse represents Victoria riding a chariot (RIC 1, The Civil Wars, $\left.\mathrm{n}^{\mathrm{0}} 15\right)^{40}$.

After receiving the news of Galba's defection, Nero is said to have initially succumbed to panic. Only after some time did he start to make preparations for a military expedition against the insurgents (Suet., Nero 43-44). His reaction is understandable, as the governor of Spain, in contrast to Vindex, had a legion stationed in the province at his disposal ${ }^{41}$. Furthermore, Galba's decision to join the mutineers meant that the military uprising against

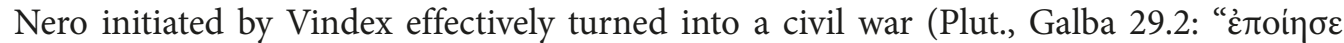
$\pi$ ó $\lambda \varepsilon \mu$ ov $\left.\dot{\varepsilon} \mu \varphi \dot{\lambda} \lambda_{\mathrm{o}} v^{\prime \prime}\right)^{42}$. Galba was immediately renounced as a public enemy, and his estate in Rome was sold (Plut., Galba 5.4-5). Nero started recruiting new soldiers from the inhabitants of the City four tribus and even from among the slaves (Suet., Nero 44.1-2). He formed a new legion from the sailors of the Misenum fleet, later also known as I adiutrix (Tac., Hist. 1.6.2; Plut., Galba 15.4; Suet., Galba 12.2) ${ }^{43}$. In the opinion of P. A. Brunt, based on the information provided in Historiae by Tacitus, Nero then called for the Illyrian legions to come to Rome, but the regiments only reached Rome at the time of the emperor's death (Tac., Hist. 1.9.3) ${ }^{44}$. Other military regiment created with the Caspian expedition in mind, such as the legion I Italica, were also to take part in the war on Nero's side (Tac., Hist. 1.6.2 ${ }^{45}$. Those troops were probably meant to wait in Italia for the arrival of Gallic rebels ${ }^{46}$.

L. Verginius Rufus, the army legate for the Upper Germania military zone was in charge of suppressing the uprising (Cass. Dio 63.24.1) ${ }^{47}$. There is no certainty on the issue whether he was given such an order by Nero or decided to act on his own ${ }^{48}$. Rufus

40 See: Ibid. P. 257.

41 Shotter D. C.A. A Time-Table... P. 67.

42 See: Fluss. Iulius... S. 887.

43 See also: Ritterling E. Legio... S. 1381; Lörincz B. Legio I Adiutrix // Les légions de Rome sous le Haut-Empire / éd. par Y. Le Bohec. Vol. 1. Lyon, 2000. P. 152.

44 Brunt P.A. The Revolt... P. 540; see also: Shotter D. C. A. A Time-Table... P. 68.

45 Source information about the formation of the legio I Italica: Suet., Nero 19.2; see also: Kolendo J. Le recruitment des légions au temps de Néron et la création de la legio I Italica // Limes. Akten des XI. Internationalen Limeskongresses. Budapest, 1977. P. 399-408; Kolendo J. Sur la date de la création de la legio I Italica // Studia in honorem Borisi Gerov. Sofia, 1990. P. 128-133; Absil M. Legio I Italica // Les légions de Rome sous le Haut-Empire. Éd. par Y.Le Bohec. Vol. 1. Lyon, 2000. P. 227.

46 Shotter D. C. A. A Time-Table... P. 68.

47 Brunt P. A. The Revolt... P. 540. - Brunt deems it possible that the armies stationed on the banks of Rhode had started preparations for war with Vindex before an official order from Rome came through. It should be noted that the region of Upper Germania (Germania superior) and Lower Germania (Germania inferior) formally became separate provinces during the reign of Domitian (81-96 A.D.); before those provinces were part of Belgic Gaul (Gallia Belgica) with separate military zones. For more information on the date of creating the Germania superior province, see e.g.: Schumacher L. Römische Kaiser in Mainz. Im Zeitalter des Principats (27 v. Chr. - 284 n. Chr.). Bochum, 1982. S. 55.

${ }^{48}$ Shotter is convinced that the news about Vindex's revolt reached Verginius Rufus earlier than it did reach Nero. This assumption is certainly correct, given the geographical distance between them. See: Shotter D. C. A. A Time-Table... P. 64. 
mobilized all the Upper Germania legions, three in total: IV Macedonica and XXII Primigenia from Mogontiacum (Mainz) and XXI Rapax from Vindonissa (Windisch), including an unknown number of auxiliary troops ${ }^{49}$ as well as a part of Lower Germania regiments (detachments of vexillationes), in addition to some of the region's legionary troops and auxiliary task force that left the province under the command of Fonteius Capito (see Tac., Hist. 1.53.2: "vexillis inferioris Germaniae" and 4.17.3: "fuisse inter Verginii auxilia Belgas") ${ }^{50}$. He left Mogontiacum for Gaul, more precisely, for Vesontio (Besançon) that could have been the centre of Vindex's rebellion. The detailed route taken by the Germanic army is not known. Charles L. Murison gives the following itinerarium: Mogontiacum (there Upper Germanic army was joined by the Lower Germanic troops) Argentorate (Strasbourg) - Cambes - Vesontio ${ }^{51}$.

At the point when the Germanic army arrived in Gaul and laid siege to Vesontio, Vindex was near Lugdunum, leading a siege and trying to take control over the city. Having received the message about Rufus's arrival, he made his way to the north to meet his adversary. He did not wait for Galba and his army. Cassius Dio gives an interesting account of a face-to-face meeting between Verginius Rufus and Vindex, close to Vesontio. In his opinion, the military leaders decided to rebel against Nero together. The sudden change of sides resulted in a tragic misunderstanding: according to Dio and Plutarch, the Rufus's troops from over the Rhine were unaware of the agreement made between the leaders, and when they saw armed Vindex's soldiers, they attacked them starting a bloody battle (Cass. Dio 63.24.2-4; Plut., Galba 6.3; Tac., Hist. 1.51.1; 4.57.2) ${ }^{52}$. As a result of this fight, the Gallic army was decimated (20.000 rebels are said to have been killed) and Vindex himself committed suicide (Plut., Galba 6.3; Suet., Galba 11; Cass. Dio 63.24.4; Zon. 11.13.C). The battle of Vesontio took place, probably, at the beginning of May 68 AD, although the actual date of the combat remains unknown ${ }^{53}$.

The account of the events given by Cassius Dio in fragments of his Roman History has been intensely debated in historiography. Some scholars are inclined to accept the hypothesis that there was an agreement between Vindex and Rufus, which means that Rufus committed an act of treason (by implication, also seeing the battle at Vesontio as a tragic mistake $)^{54}$. Still, in the eyes of others, Verginius Rufus, in spite of Cassius Dio account, was faithful to Nero until the end ${ }^{55}$. As it is often the case, with hardly any

49 This was established by Tac., Hist. 1.53.2: “in exercitu (...), quo et bello adversus Vindicem universus adfuerat”; see: Murison Ch. L. Galba, Otho... P.9. Fn. 26.

${ }^{50}$ Murison believes that at least one whole legion, meaning I Germanica from Bonna (Bonn) was sent to meet Vindex. Murison Ch.L. Galba, Otho... P.9. Fn. 25.

${ }^{51}$ Murison Ch.L. Galba, Otho... P. 8-10; Vesontio as the centre of Vindex's rebellion: Levick B. L. Verginius Rufus and the Four... P. 327.

52 See: Brunt P. A. The Revolt... P. 538.

53 The date of the Vesontio battle is of much controversy in the literature: Brunt believes it took place at the beginning of May: Brunt P. A. The Revolt of Vindex and the Fall of Nero. P. 540-541. Shotter expresses the view that the battle began at the end of April 68 A. D.: Shotter D. C. A. A Time-Table... P. 69; Murison assumes that the period from $10^{\text {th }}$ May to $15^{\text {th }}$ May was the most likely one: Murison Ch. L. Galba, Otho... P. 26. Wiedermann chooses the end of May: Wiedemann T.E. J. From Nero... P. 260.

${ }^{54}$ For example, Brunt P.A. The Revolt... P.538; Shotter D.C.A. A Time-Table... P.69. - An interesting proposition was put forward by Murison. In his opinion, Rufus, upon receiving the news of Vindex's rebellion, started to prepare for a military expedition against him and left Mogontiacum with his troops. However, when he learnt that governor Galba joined the revolt, his enthusiasm to quell the motus Vindicis waned, and he also revolted against Nero (Murison Ch. L. Galba, Otho... P. 20).

${ }^{55}$ See e.g.: Levick B. L. Verginius Rufus... P. 330, 335; Morgan G. 69 A. D... P. 25, 28. 
historical sources on the subject available, there is no definitive answers to this question.

One other remarkable fact about the battle of Vesontio is that the Germanic soldiers gave to their leader the title of emperor. The sources disagree as to when it happened (before or after the battle $\mathrm{e}^{56}$ ), so it is quite impossible to make any assumptions. Perhaps, Verginius was honored with the title of emperor only after Nero's death ${ }^{57}$. It is, however, certain that Verginius Rufus was proposed to accept the title of Caesar, which, as confirmed by Tacitus, was known to everyone in the Empire (Tac, Hist. 1.8.2: "an imperare noluisset dubium: delatum ei a milite imperium conueniebat"). In any case, Verginius Rufus refused to accept the proposal of the legion, as he believed that only the senate in Rome could grant the imperial title (Tac, Hist. 1.8.2; Cass. Dio 63.25.1-2). The engraving on his tombstone, recorded in one of the letters by Pliny the Younger, said that whatever he did while fighting with Vindex, he did not for himself, but for his country: "Hic situs est Rufus, pulso qui Vindice quondam Imperium adservit non sibi, sed patriae" (Plin., Epist. 6.10.4; 9.19.1; see also Cass. Dio 68.2.4 $)^{58}$. No sources recall what Rufus did after the battle of Vesontio; it is possible that he may have returned to Mogontiacum ${ }^{59}$.

Cassius Dio recounts that when Nero was informed about the treason of Verginius Rufus, he sent armed troops under the command of Rubrius Gallus (Cass. Dio 63.27.1) and P. Petronius Turpilianus (Cass. Dio 63.27.1a) to Gaul. As discussed above, it is not possible to ascertain whether the legate of the Upper Germanic army actually betrayed the emperor; for all we know, he may have remained faithful until the end. However, it is possible that the information received by Nero may have implied a different scenario altogether. The troops faithful to Nero, presumably, including the recently formed legio I Italica, with the Caspian expedition in mind, left Rome with the mission of suppressing the rebellion ${ }^{60}$.

At the same time, Galba, initially toying with the idea of suicide after Vindex's defeat under Vesontio (Suet., Galba 11), sent a letter to Verginius Rufus entreating him to join the fight to restore freedom to Romans and then withdrew to a Spanish town called Clunia (Plut., Galba 6.5). We do not know whether Rufus responded to the letter and what his views on it were. Tacitus wrote that the armies of Upper Germania were one of the last to denounce Nero ("Germanici exercitus ... tarde a Nerone desciverant"), and Verginius personally did not support Galba immediately (Tac., Hist. 1.8.2: "nec statim pro Galba Verginius"). Yet again, the issue in question is difficult to evaluate, as we know that Verginius was given the title of the emperor by his army after the battle of Vesontio.

Nero became more estranged. New governors were joining Galba, possibly even before the battle of Vesontio (Plut., Galba 6.1). It is not known what choice was made by the previously mentioned Petronius Turpilianus. Tacitus and Plutarch were of the opinion that he remained faithful to the emperor (see Tac., Hist. 1.6.1, where even in 69 AD he

56 According to Cassius Dio (63.25.1), it happened after the battle, whereas Plutarch (Galba 6.2) states that Verginius Rufus was given the title of the emperor by soldiers several times, including the one after the battle of Vesontio (Plut., Galba 6.3).

57 Winniczuk L. Pliniusz Młodszy w świetle swoich listów i mów. Warszawa, 1987. P. 21.

58 Cf. Brunt P. A. The Revolt... P.539. Fn. 1.

59 So thinks Shotter D. C. A. A Time-Table... P.70; this is seen as doubtful by: Murison Ch. L. Galba, Otho... P.26. Fn. 88 .

60 Brunt P. A. The Revolt... P. 540. - Brunt supports the assumption that the legio I Italica was sent to suppress Vindex's rebellion, as it would be hard to explain otherwise its presence in Lugdunum at the beginning of 69 A. D. confirmed by Tacitus (Hist. 1.74.2). 
was described as dux Neronis; Plut., Galba 15.2), whereas Cassius Dio suggested that he joined Galba (Cass. Dio 63.27.1a). It could have been possible as Suetonius wrote that Nero received the news about the rebellion of the remaining armies (Suet., Nero 47.1: "defectio ceterorum exercituum"). There are considerable doubts as to whether that actually happened, as Petronius Turpilianus was executed during Galba's march to Rome (Tac., Hist. 1.6.1 $)^{61}$. D. C. A. Shotter is, however, convinced that in May 68 AD Rubius Gallus also became one of Galba's supporters ${ }^{62}$.

The fraction of the governor of Spain also had the backing of Nymphidius Sabinus, the prefect of the praetorian guards in Rome. He was hoping to be adequately remunerated for his support, to keep his position and powers in Rome as Galba was a man of advanced age (Plut., Galba 8.1-2). Sabinus persuaded his soldiers to support the cause by promising to pay out a donativum in the sum of 7500 denari, if they were to recognize Galba as the emperor (Plut., Galba 8.1-2) ${ }^{63}$. The choice was made during the night 8-9 June 68 AD; on the next day, the senate decided that Nero was a public enemy and proclaimed Galba the new emperor. Deserted by everyone, Nero committed suicide, probably, on 10 June 68 AD (source information on the death of Nero: Suet., Nero 49; Cass. Dio 63.29.1). It was a dawn of a new era in the history of imperial Rome.

As could be seen above, many issues related to rebellion of Vindex are unclear, mostly due to insufficient sources recounting the events. There is no doubt, however, that the events in Gaul were of key importance for the future of the Roman Empire. They marked the beginning of the end of Nero's reign (by many regarded as a tyrant), were a prelude to "the long year", and put the governor of Spain, Servius Sulpicius Galba, on the throne. The ultimate aim of the revolt, to crown a new emperor of higher character in Rome, was achieved, although only after Vindex's tragic death. Caius Iulius Vindex, forced to commit suicide after losing the battle in Vesontio, was remembered by Romans as a brave freedom fighter, who did it not to receive honors (he did not see himself as the successor of Nero) but, perhaps, idealistically, for the good of the Empire and the whole gens humana. After his death, the leader of the anti-Nero revolt was honored by Emperor Galba with a public funeral (Plut., Galba 22.2). In the account of Pliny the Elder, Romans worshipped the memory of Iulius Vindex, the one who defended freedom against the tyrant (Plin., Nat. Hist. 20.57: "Iulium Vindicem, adsertorem illum a Nerone libertatis"). The memory of his deeds, although probably waning over the years, was preserved until the times of the late antiquity: Vindex was, for example, mentioned twice by the author of the collection "Historia Augusta" or "Scriptores Historiae Augustae" (H. A., Alex. Sev. 1.7; Firm. 1.1). Finally, I would like to add that the revolt of Vindex is known to the Polish audience from Henryk Sienkiewicz's epilogue to his well-known novel "Quo vadis": A substantial part of the epilogue is devoted to the description of Vindex's rebellion ${ }^{64}$.

\section{References}

Absil M. Legio I Italica. Les légions de Rome sous le Haut-Empire. Éd. par Y.Le Bohec. Vol.1. Lyon, De Boccard Publ., 2000, pp. 227-238.

\footnotetext{
61 See: Shotter D. C. A. A Time-Table... P. 71.

62 Ibid. P. 71.

63 See: Brunt P. A. The Revolt... P. 542.

64 Sienkiewicz H. Quo vadis. Kraków, 2010. P.417-419.
} 
Bessone L. Le vicissitudini di Gulio Civile e la datazione delle battaglia di Vesontio. Latomus. 1978, vol.37, fasc.3, pp. 705-713.

Bloom J. J. The Jewish Revolt against Rome, A. D. 66-135. A Military Analysis. Jefferson; London, McFarland \& Company Inc. Publ., 2010, 286 p.

Brunt P. A. The Revolt of Vindex and the Fall of Nero. Latomus, 1959, vol. 18, fasc. 3, pp. 531-559.

Byra M. Wojna o tron cezarów (68-69 r. n.e.). Oświęcim, Napoleon V Publ., 2014, 367 p.

Domaszewski A. von. Geschichte der römischen Kaiser. Bd. 2. 3 Aufl. Leipzig, Quelle \& Meyer Publ., 1921, $328 \mathrm{~S}$.

Fluss M. Iulius (Nr. 534). Realencyclopädie der classischen Altertumswissenschaft X. Hrsg. von W. Kroll. Stuttgart, J. B. Metzlersche Verlag Publ., 1918, S. 879-881.

Fluss M. Sulpicius (Nr. 63). Realencyclopädie der classischen Altertumswissenschaft IV A. Hrsg. von W. Kroll, K. Mittelhaus. Stuttgart, J. B. Metzlersche Verlag Publ., 1931, S. 772-801.

Grant M. Neron. Warszawa, Państwowy Instytut Wydawniczy Publ., 1980, 218 s.

Greenhalgh P. A. L. The Year of Four Emperors. London, Weidenfeld and Nicolson Publ., 1975, 271 p.

Griffin M. T. Nero. The End of a Dynasty. $3^{\text {rd }}$ ed. London, Routledge, 2000, 320 p.

Hainsworth J. B. The Starting-Point of Tacitus' Historiae: Fear or Favour by Omission? Greece \& Rome. Second Series. 1964, vol. 11, pp. 128-136.

Hainsworth J. B. Verginius and Vindex. Historia, 1962, vol. 11, pp. 86-96.

Henderson B. W. Civil War and Rebellion in the Roman Empire A. D. 69-70. A Companion to the 'Histories' of Tacitus. London, MacMillan and Co. Publ., 1908, 345 p.

Henderson W. Life and Principate of the Emperor Nero. London, Methuen \& Co. Publ., 1903, 529 p.

Hohl E. Domitius (Nr. 29). Realencyclopädie der classischen Altertumswissenschaft Suppl. III. Hrsg. von W. Kroll. Stuttgart, J. B. Metzlersche Verlag Publ., 1918, S. 349-394.

Kienast D., Eck W., Heil M. Römische Kaisertabelle. Grundzüge einer römischen Kaiserchronologie. 6. bearb. aufl. Darmstadt, WBG Publ., 2017, 368 S.

Kolendo J. Le recruitment des légions au temps de Néron et la création de la legio I Italica. Limes. Akten des XI. Internationalen Limeskongresses. Budapest, Akadémiai Kiadó Publ., 1977, pp. 399-408.

Kolendo J. Sur la date de la création de la legio I Italica. Studia in honorem Borisi Gerov. Sofia, Sofia Press Publ., 1990, pp. 128-133.

Kozłowski J., Królczyk K. Aspekty polityczne i militarne "roku czerech cesarzy" (68-69 r. po Chr.), part 1. Do śmierci Galby. Studia Europaea Gnesnensia, 2015, vol. 11, ss. 29-54.

Kozłowski J., Królczyk K. Aspekty polityczne i militarne "roku czerech cesarzy" (68-69 r. po Chr.), part 2. Od śmierci Galby do zwycięstwa Wespazjana. Studia Europaea Gnesnensia, 2015, t. 12, ss. 33-60.

Kraay C.M. The Coinage of Vindex and Galba, AD 68, and the Continuity of the Augustan Principate. Numismatic Chronicle, 1949, vol.9, pp. 129-149.

Levick B.L. Verginius Rufus and the Four Emperors. Rheinisches Museum für Philologie, 1985, Bd.128, S. 318-346.

Lőrincz B. Legio I Adiutrix. Les légions de Rome sous le Haut-Empire. Éd. par Y.Le Bohec. Vol. 1. Lyon, De Boccard Publ., 2000, pp. 151-158.

Millar F. A Study of Cassius Dio. Oxford, Oxford University Press, 1964, 239 p.

Mommsen T. Der letzte Kampf der römischen Republik. Mommsen T. Historische Schriften. Bd. 1. Berlin, Weidmann Publ., 1906, S. 333-352.

Morgan G. 69 A.D. The Year of Four Emperors. Oxford, Oxford University Press, 2006, 322 p.

Murison Ch. L. Galba, Otho and Vitellius: Careers and Controversies. Hildesheim; Zürich; New York, Olms Publ., 1993, 175 p.

Murison C. L. Rebellion and Reconstruction: Galba to Domitian. An Historical Commentary on Cassius Dio's Roman History, Books 64-67 (A. D. 68-96). Atlanta (Georgia), Scholar Press Publ., 1999, 291 p.

Nagl A. Salvius (Nr. 21). Realencyclopädie der classischen Altertumswissenschaft I A. Hrsg. von W. Kroll, K. Witte. Stuttgart, J. B. Metzlersche Verlag Publ., 1920, S. 2035-2055.

Pfeiffer S. Die Zeit der Flavier. Vespasian - Titus - Domitian. Darmstadt, WBG Publ., 2009, 134 S.

Ritterling E. Legio. Realencyclopädie der classischen Altertumswissenschaft XII. Hrsg. von W. Kroll. Stuttgart, J. B. Metzlersche Verlag Publ., 1924-1925, S. 1211-1829.

Rogers R. S. Heirs and Rivals to Nero. Transactions and Proceedings of the American Philological Association. Vol. 86. 1955, pp. 190-212.

Schumacher L. Römische Kaiser in Mainz. Im Zeitalter des Principats (27 v. Chr. - 284 n. Chr.). Bochum, Studienverlag Dr. N. Brockmeyer Publ., 1982, 119 S.

Shotter D. C. A. A Time-Table for the "Bellum Neronis". Historia, 1975, vol. 24, pp. 59-74.

Sienkiewicz H. Quo vadis. Kraków, Greg Publ., 2010, 460 s. 
Smallwood E. M. The Jews under Roman Rule. From Pompey to Diocletian. Leiden, Brill, 1976, 595 p.

Syme R. Tacitus. $2^{\text {nd }}$ ed. Vol. 1. Oxford, Clarendon Press, 1997, 464 p.

Turner E. G. Tiberius Iulius Alexander. Journal of Roman Studies. 1954, vol. 44, pp. 54-64.

Waldherr G. H. Nero. Eine Biographie. Regensburg, Pustet Publ., 2005, 292 S.

Wellesley K. The Year of the Four Emperors. $3^{\text {rd }}$ ed. London; New York, Routledge, 2000, 238 p.

Wiedemann T. E. J. From Nero to Vespasian. The Cambridge Ancient History. $2^{\text {nd }}$ ed. Vol. 10. The Augustan Empire, 43 B. C. - A. D. $69.5^{\text {th }}$ ed. Eds A. K. Bowman, E. Champlin, A. Lintott. Cambridge, Cambridge University Press, 2009, pp. 256-282.

Winniczuk L. Pliniusz Młodszy w świetle swoich listów i mów. Warszawa, Państwowe Wydawnictwo Naukowe, 1987, $491 \mathrm{s.}$

Ziegler K. Xyphilinos. Realencyclopädie der classischen Altertumswissenschaft IX A. Hrsg. von K. Ziegler. Stuttgart, A. Druckenmüller Publ., 1967, S.2132-2134.

Received: 17.01 .2018

Accepted: 31.05 .2018 